\title{
Katılımeı Bütçeleme ve Kent Konseylerinde Katılımcı Bütçe Algısı: Manisa Yunusemre Belediyesi Kent Konseyi Örneğiं*
}

\author{
Sema ÇAKIR ${ }^{* *}$
}

\author{
Gül KAYALIDERE ${ }^{* * *}$
}

\begin{abstract}
$\ddot{O} Z$
Kamu yönetiminde yaşanan gelişmelerle birlikte, halkın bütçelerin hazırlanma sürecine doğrudan katılımlarını ve kamu harcamaların izlemelerini sağlayan bir model olarak katılımcı bütçeleme anlaylşı gündeme gelmiştir. Toplumun yerel düzeyde katılımcllığını esas alan bütçeleme tekniği, bütçeleme sürecinin temel belirleyicisi konumundaki siyasi aktörlerin kararlarını denetleyici ve yönlendirici bir yaklaşımdır. Yerel yönetimlerde katılımcı bütçeleme anlayışı çerçevesinde halkın katılımını arttırmak ve bütçeleme sürecinde tercihlerini yansıtmak amacıyla sürdürülebilir kentleşmeyi sağlamak için kent konseyleri oluşumu ortaya çıkmıştır. Yerel halk temsilcilerinin bulunduğu kent konseyleri katılımcı bütçeleme anlayışı ile belediye bütçelerinin hazırlanması sürecinde önem kazanır. Dolayısıyla, katılımcı bütçeleme süreci ile kent konseyleri arasında karşılıklı bir etkileşim söz konusudur.

Demokrasinin yaşama geçirildiği en temel birimler yerel yönetimlerdeki kent konseyleridir ve kent konseyleri üyeleri bütçe hakkında yeterli bilgi ve beceriye sahip değil ise alınacak kararlarda kamu kaynaklarının israfi söz konusu olabilir. Bu noktada kent konseyi üyelerinin genel bütçe bilgisi ve bütçeleme sürecine yönelik bilgi dağarcıkları önem kazanmaktadır. Bütçe algılarının ölçülmesi, kent konseylerinin öneminin farkındalığını arttırabileceği düşünülmektedir.

Bu amaçla, Manisa Yunusemre Belediyesi Kent Konseyi üyelerinin bütçe algılarını ölçmeye yönelik olarak 91 kişilik bir örneklem grubuna 5'li Likert Tipi anket uygulaması yapılmış ve SPSS programında analizleri gerçekleştirilmiştir.

Çalışmada, genel bütçe bilgisi, bütçeleme süreci ve kent konseylerinin öneminin farkındalı̆̆ına ilişkin değişkenler oluşturularak cinsiyet ve eğitim düzeyi açısından farklılık gösterip göstermediği incelenmiştir. Araştırma sonucunda katılımclların bütçe sürecine iliş̧kin bilgi dağarcı̆̆ arttıkça, farkındalık düzeyinin arttırdığı ancak bütçe hakkında genel bilgi dağarcı̆̆ ile farkındalık düzeyi arasında böyle bir ilişsi bulunmadĭ̆ tespit edilmiştir. Ulaşılan bu durum, kent konseyi üyelerinin aslında teknik olarak genel bütçe bilgisine sahip olmamalarına karşın bütçe süreci hakkında bilgili olduklarını ortaya koymuştur.
\end{abstract}

Anahtar Kelimeler: Yerel Yönetimler, Kent Konseyleri, Katılımcı Bütçeleme

Jel Sınıflandırma Kodları: H70, H83

\footnotetext{
* Bu çalışma Manisa Celal Bayar Üniversitesi Bilimsel Araştırma Projeleri Koordinatörlüğü tarafindan desteklenen 2017-214 no'lu Yüksek Lisans Tez Projesinden türetilmiştir. Ayrıca, İzmir Uluslararası İktisadi ve İdari Bilimler Kongresi (2018)'nde sunulan "Katılımcı Bütçe Bağlamında Manisa Yunusemre Belediyesi Kent Konseyi'nin Bütçe Algısını Ölçmeye Yönelik Bir Araştırma" konulu bildiri çalışmasının genişletilmiş ve yeniden düzenlenmiş halidir.

** Manisa Celal Bayar Üniversitesi, Sosyal Bilimler Enstitüsü, Maliye Teorisi ABD, semacakiir@gmail.com

*** Doç. Dr., Manisa Celal Bayar Üniversitesi, İktisadi ve İdari Bilimler Fakültesi, Maliye Bölümü, gul.kayalidere@cbu.edu.tr
} 


\title{
Participatory Budgeting and Perception of Participatory Budget in City Councils: The Case of City Council of Manisa Yunusemre Municipality
}

\begin{abstract}
Along with the developments experienced in public administration, perception of people on participatory budgeting as a model, which enables them to directly participate in budget preparation process and monitor public expenses, has become a current issue. Budgeting method based on participation of people on local level is a supervising and directing approach for decisions of political actors as key determinants of the budgeting process. In local governments, city councils have been formed for increasing participation of people and ensuring sustainability urbanization on the purpose of reflecting their preferences in budgeting processes from the frame of participatory budgeting. City councils with local community representatives gain importance in the process of preparing municipal budgets with participatory budgeting approach. Consequently, there is a mutual interaction between the participatory budgeting process and city councils.

The basic units where democracy can be actualized are the city councils of local governments and if, the members of city councils do not have sufficient knowledge and experience on budgets, public resources might be wasted due to decisions made by these councils. At this point, the general budget experience and budgeting process knowledge of the city council members become important. It is thought that measuring budget perceptions may increase awareness of the importance of city councils.

For this purpose, a 5-point Likert-type questionnaire was applied to a sample group of 91 people in order to measure the budget perception of the members of the City Council of Manisa Yunusemre Municipality

In the study, it was examined whether the variables related to the general budget information, budgeting process and awareness of the importance of city councils were formed and whether they differed in terms of gender and educational level. As a result of the research, it was determined that as the knowledge level of the budget process increased, the level of awareness increased but there was no such relationship between the general knowledge of budget and the level of awareness. This situation revealed that the members of the city council, although they did not have technical knowledge in general, were aware of the budget process.
\end{abstract}

Key Words: Local Administrations, City Councils, Participatory Budgeting

JEL Classification Codes: H70, $H 83$

\section{GíRiş}

Kamu yönetimi anlayışında meydana gelen değişimler ile katılım kavramı çerçevesinde katılımcı bütçeleme anlayışının güçlenmesiyle birlikte vatandaşların beklenti ve talepleri daha çok göz önünde bulundurulması ve bu beklentilere uygun olarak politika belirlenmesi ve uygulanması amaçlanmıştır. Katılımcı bütçe kavramı daha etkin bir hizmet anlayışı ve daha saydam bir süreç beklentisiyle birlikte yerel yönetimlere olan güvenin arttırılması, kamu gücünün kötüye kullanılmasının engellenmesi, vatandaşların beklentilerinin daha fazla karşılanması ve taraflar arasındaki uyumun sağlanması amacıyla büyük önem arz etmektedir.

Kentlerin öncelikli sorunlarının tespiti ve çözümü konusunda ülkemizdeki çok ortaklı ve aktif katılımlı mekanizmaların en güçlü aracı olan kent konseylerinin önemi göz ardı edilemez. Kent konseylerinin etkinliği, toplumun her kesiminden insanı hem kararlara ortak ederek hem de uygulamaların içine dahil ederek gerçekleştirilebilir. Ancak bu noktada kaynakların kıt, taleplerin sonsuz olduğunu göz önünde bulundurulmalıdır ve ekonomik kararların etkin ve etkili şekilde alınması doğru hazırlanan ve uygulanan bütçe ile mümkün olabilecektir. 
Yapılan çalışmada, Manisa Yunusemre Kent Konseyi üyelerinin bütçe sürecindeki önemlerinin farkında olup olmadıkları saptanmaya çalışılmış bu bağlamda mevcut bütçe bilgi düzeyleri araştırılmıştır. Öncelikle katılımcı bütçeleme kavramı ve Türkiye'de katılımc1 bütçelemeyi hayata geçirebilecek kurum olarak kent konseyleri hakkında bilgi verilmeye çalışılmıştır. Sonrasında ise Manisa'nın iki merkez ilçesinden biri olan Yunusemre Belediyesi'nin Kent Konseyi üyeleri ile bir anket çalışması yapılmış ve sonuçları değerlendirilmiştir.

\section{KATILIM KAVRAMI VE KATILIMCI BÜTÇELEME ANLAYIŞI}

Yerel yönetim birimleri günlük hayatımızı etkileyen hizmetleri yerine getiren en önemli kuruluşlardır. Bu noktada katılım kavramı, seçim ve seçime ilişkin faaliyetler dışında, kamu hizmetleriyle ilgili temel kararların alınması ve uygulanması aşamalarına karardan etkilenenlerin dahil olması ve sürece katkıda bulunması olarak nitelendirilir (Eryılmaz, 2013:62).

Her ne kadar katılım kavramı vatandaşlar tarafindan 'oy verme' şeklinde algılansa da günümüzde katılımcılık, toplumdaki her kesimin örgütlü katılımıyla, bireyin kendisinin doğrudan doğruya katılımını öne çıkaran bir yaklaşım olarak ifade edilmektedir (Tekeli, 1992:37). Katılım düzeyi ister bireysel ister örgütsel düzeyde olsun, kavramın amacını gerçekleştirebilmesi için yönetim mekanizması üzerinde bir etkiye sahip olması gerekmektedir.

Son dönemde küreselleşme süreciyle birlikte devlet bütçesi alanında değişimler yaşanmaya başlanmıştır. İyi bir bütçe sistemi ile, devletin mali disiplinini sağlayan, kaynakları önceliklere göre tahsis eden, bu kaynakları en az maliyetle ve amaca uygun bir şekilde kullanan ve kullandığı kaynağın hesabını verebilen bir yapı hedeflenir (Cura, 2003: 144). Bu bağlamda, kamusal ihtiyaçların alınan mali nitelikteki kararlar doğrultusunda yeterince karşılanmadığı gerekçesiyle belediyeler ve sivil toplum kuruluşları aracıllğıyla sosyal bütçe düzenlemeleri gündeme gelmiştir (Yalçın, 2015:314). Genellikle halkın katılımı ve tercihleri doğrultusunda yerel yönetimlerin harcama önceliklerinin belirlendiği katılımcı bütçeleme anlayışında vatandaşlar doğrudan karar verme sürecinde yer aldıkları için yıl boyunca birçok forum gerçekleştirilmekte ve böylece vatandaşlar kamu kaynaklarının ne şekilde kullanıldığını izleme, sosyal politikalar arasında tercihte bulunma ve kamusal kaynakları önceliklerine göre dağıtma firsatı bulabilmektedir. $\mathrm{Bu}$ uygulama sayesinde gelir düzeyi düşük ve politik açıdan dışlanmış kesimlerin de karar alma sürecine katılma fırsatı bulunmaktadır (Özen ve Yontar, 2009:284).

Gelişmiş ve gelişmekte olan pek çok ülkede yerel düzeyde katılımcı uygulamaların hayata geçirilmesi sonucu kamusal karar alma sürecinde vatandaş katılımının artmasıyla alınacak kamusal kararlarda, toplumsal sorunlara olan duyarlılığın, kamusal mal ve hizmet sunumunda etkinliğin, kamusal kararların şeffaflığının ve yetkililerin hesap verebilirliğinin de artacağı düşünülmektedir (Uslu ve Yılmaz, 2017:142). Ancak kamusal kararların uygulama aracı olan bütçelerin etkinliğinden söz edebilmek için nasıl bir katılım olmalı sorusunu tartışmak ve bütçeleme sürecindeki katılım unsurlarını tespit etmek gerekmektedir. 
Hizmet önceliğinin önemli olduğu yerel yönetim birimlerinde katılımc1 bütçeleme anlayışı ile halkın bütçeleme sürecine katılımı mümkün olmaktadır. Söz konusu süreçte dikkat edilmesi gereken en önemli unsur vatandaşların katılımcı bütçenin planlamasına dahil edilmesi olarak ifade edilmektedir. Kentsel hizmet ve yatırımlara ilişkin bilgi arzını yerel yönetimler yaparken talep tarafını vatandaşların ve sivil toplumun oluşturması gerekmektedir. Bu noktada ilişkinin kurulabilmesi için hizmetlerden yararlananların yani vatandaşların çıkarlarını savunan sivil toplum örgütleriyle hizmetleri sunan kuruluşları bir araya getirebilecek platformlar oluşturulmalıdır.

\section{TÜRKIYE'DE KATILIMCI BÜTÇELEMEYE YÖNELIKK BİR UYGULAMA: KENT KONSEYLERI}

Belediye Kanunu kapsamında, yönetişim yaklaşımı doğrultusunda sivil toplum örgütlerinin, meslek teşekküllerinin ve diğer aktörlerin karar ve uygulamalarda yer alabilmesi amaciyla "Kent Konseyleri" uygulamasi getirilmiştir. Belediye kanunu 76. Madde'de "kentin kalkınma önceliklerini, sorunlarını ve vizyonlarını sürdürülebilir kalkınma ilkeleri temelinde tartışmak ve çözüm geliştirmek üzere, merkezi yönetimi, yerel yönetimleri, kamu kurumu niteliğindeki meslek kuruluşlarını ve sivil toplum örgütlerini bir araya getiren yönetişim mekanizmalarıdır" şeklinde tanımlanmıştır.

Yapılan düzenlemelerle ile birlikte kent konseylerine önemli fonksiyonlar yüklenmiştir. İlk olarak, kentin yaşanabilir hale gelmesi ve yaşam kalitesinin arttırılması için kentte yaşayanlar tarafından kentin hak ve hukukunun korunması; ikinci olarak, kent konseyinin kentte yaşayan insanlar arasında sosyal yardımlaşma ve dayanışmayı geliştirici bir fonksiyon üstlenmesi; üçüncü olarak, sürdürülebilir kalkınma ve gelişmenin sağlanması amacıyla hemşehrilerde bilinç oluşturulması; dördüncü olarak ise yerel düzeyde hesap verme, hesap sorma, kat1lım ve yönetişimin gerçekleştirilmesidir (Özcan ve Yurttaş, 2010: 168-169). Bu bağlamda kent konseylerinin karar alma mekanizmasındaki konumu da tartışılmaz olarak değerlendirilebilir.

Kamusal kaynakların kullanımında etkinliğin sağlanabilmesinde yerel halkın kararlara katılımı ve hizmet önceliklendirmesinin bu katılım sonucu belirlenmesi noktasında da kent konseyleri önem kazanır. Katılımcı bütçeleme, yerel yönetimlerin harcama önceliklerini halkın doğrudan katılımı ve tercihleri doğrultusunda şekillendirdiği bir bütçeleme süreci olarak nitelendirildiğinde kent konseylerinin bu süreçteki yeri yadsınamayacaktır.

\section{KATILIMCI BÜTÇELEME BAĞLAMINDA LITTERTÜRDE YAPILAN ÇALIŞMALAR}

Yerel yönetimlerde yerel demokrasinin gereklerinden bir olarak kabul edilen kent konseylerinin bütçeleme sürecinde de yerini alması katılımcı bütçe anlayışının bir gereğidir. Dolayısıyla kent konseyi üyelerinin bütçe konusundaki bilgi düzeyleri ve bütçe algıları önem kazanır. Alınacak kararlarda özellikle bütçe ile ilgili kararlarda bu süreç ile ilgili yeterliliğe sahip olmamak yanlış kararları ve sonucunda kaynak kullanımında verimsizliği beraberinde getirebilecektir. Çalışmada, Manisa Yunusemre Belediyesi Kent Konseyi üyelerinin katılımcı bütçe 
süreciyle ilişkili algıları ölçülmeye çalışılmıştır. Literatür incelendiğinde son dönemde farklı alanlarda böyle araştırmaların yapılmasından yola çıkılarak ilk kez Yunusemre Belediyesi Kent Konseyi'nde bir çalışma yapılması hedeflenmiştir.

Çalışmamızın bulgularına geçmeden önce literatürdeki araştırmalar incelendiğinde genellikle bütçe algısını ölçmeye yönelik araştırmalara rastlandığını belirtmek gerekir. Örneğin, Alkan ve Yıldız'ın 2016 yılındaki çalışması bu içeriktedir. Ancak, çalışmamızda genel bütçe bilgisi ölçümüne bizim de yer verdiğimiz düşünüldüğünde onların çalışmasının da araştırmamızla ilgili olduğu düşünülmüş ve aşağıdaki bölümde söz konusu çalışmaya ve sonuçlarına da yer verilmiştir.

Alkan ve Yıldız (2016) kamu kurumlarının bütçeleme süreçlerinde bireylerin bütçe algısını araştırdıkları çalışmalarında Dumlupınar Üniversitesi'nin personeli ve maliye bölümü öğrencilerine anket uygulamışlar ve bütçe süreçlerinde bütçe algısını analiz etmişlerdir. Anket soruları genel bütçe bilgisine, kamu kurumlarının bütçeleme sürecindeki hazırlık, uygulama ve denetim aşamalarına yönelik olarak dört ana çerçevede hazırlanmış ve sonuç olarak katılımcıların bütçe ve bütçe uygulamalarına yönelik ve bununla beraber bütçe süreçlerindeki aşamalar hakkında genel bir bilgiye sahip olduğu sonucuna varılmıştır. Katılımcıların yaş, cinsiyet ve eğitim durumları da bu bilgi düzeyinde etkilidir. Dolayısıyla çalışmada, bütçe algısının geliştirilmesine yönelik eğitici yayınların yapılması gereği vurgulanmıştır.

Dağlı (2017), Bandırma ve Çanakkale Belediye'lerinin yöneticilerinin katılımıyla gerçekleştirdiği araştırmasında, katılımcı bütçelemeye ilişkin olarak yöneticilerin tutum ve algılarını analiz etmiştir. 97 belediye yöneticisine ulaşılarak yapılan çalışmanın sonucunda, katılımcı bütçelemenin uygulanabilirliğinin yöneticilerin tutum ve davranışlarına göre değişiklik göstereceği vurgusu yapılmıştır.

Yıldız ve Alkan (2017), çalışmalarında Kütahya'da Dumlupınar Üniversitesi'nde okuyan öğrencilere anket uygulayarak, katılımcı bütçe perspektifinden bütçe algılarını ölçmeye çalışmışlardır. Katılımcı bütçe algısına yönelik katılımcılık ve şeffaflık etkinliği olmak üzere iki temel faktör belirlemişlerdir. Araştırmalarının sonucunda katılımcı bütçeleme uygulamalarına ilişkin beklentiler ve şeffaflık sürecinin geliştirilmesine yönelik çalışmalar arttıkça bireylerin, bütçe uygulamalarının yaşam standartları üzerindeki etkisini güçlendirdiği algısına katkı sağladığını düşündükleri saptanmıştır.

Altıngöz Zarplı (2017)'nın araştırmasında Nilüfer, Osmangazi, Tepebaşı, Altındağ ve Çanakkale Belediyeleri ile görüşmeler gerçekleştirmiş ve katılımcı bütçe mekanizmalarının değerlendirmesini yapmıştır. Sonuç olarak, Türkiye'de katılımcı bütçenin yeni bir uygulama olduğu vurgusu yapılmaktadır. Ayrıca çalışmada, katılımcı bütçe uygulamalarında belediyelerdeki yönetici ve personelin bakış açısı, bilinç düzeyi ve hukuki altyapı gibi faktörlerin esas oluşturduğunu ifade edilmektedir. 


\section{KATILIMCI BÜTÇE ALGISINI ÖLÇMEYE YÖNELİK BİR ARASTTIRMA: MANISA YUNUSEMRE BELEDIYESI KENT KONSEYİ}

Kent konseyleri, hizmet önceliklendirmesinin yanı sira yerel halkı karar alma süreçlerine ekleyerek kamusal kaynakların etkin kullanımına da hizmet etmektedir. Konseyler, bütçe sürecinde hesap vermeyi sağlamaları açısından katılımcı bütçeleme anlayışı çerçevesinde önemli bir adımı oluşturmaktadır. Toplumun yerel düzeyde katılımcılığını esas alan bu bütçeleme tekniği, bütçeleme sürecinin temel belirleyicisi konumundaki siyasi aktörlerin kararlarını denetleyici ve yönlendirici bir yaklaşımdır. Dolayısıyla, katılımcı bütçeleme süreci ile kent konseyleri arasında karşılıklı bir etkileşim söz konusudur.

Katılımcı bütçeleme, yerel yönetimlerin harcama önceliklerini halkın doğrudan katılımı ve tercihleri doğrultusunda şekillendirdiği bir bütçeleme süreci olması açısından kent konseylerinin bu süreçteki yeri yadsınamayacaktır. Yapılan çalışmada Manisa Yunusemre Belediyesi Kent Konseyi üyelerinin katılımcı bütçe bağlamında bütçe algılarını ölçmeye yönelik iki amaç bulunmaktadır:

Birinci amac1: "kent konseyi üyelerinin genel bütçe bilgisi ve bütçeleme sürecine dair bilgi düzeyinin ölçülmesidir"

İkinci amacı ise: "kent konseyi üyeleri olarak katılımcı bütçe açısından yapılan işlerde ve alınan kararlarda kent konseyi olarak öneminin farkinda olup olmadiklarının belirlenmesidir."

Buradan hareketle; yerel yönetim bütçelerinin hazırlanması sürecinde kıt kaynakların etkin ve verimli kullanılabilmesi ve denetimlerinin sağlanabilmesi amacıyla yerel halkın katılımı ile oluşturulan kent konseylerinin bu süreç içerisindeki bütçe algılarının ölçülmesi ve yeterli bilgi ve beceriye sahip olup olmadığını belirmek çalışmanın odak noktasını oluşturmaktadır.

\subsection{Araștırmanın Veri Seti ve Yöntemi}

Araştırmanın veri seti, tek örneklem grubu olan ve 120 üyeden oluşan Manisa Yunusemre Belediyesi Kent Konseyi üyelerine uygulanan anket formlarından elde edilen cevaplardan oluşmaktadır. Konsey bünyesinde çocuk meclisi ve aktif olmayan çalışma grupları mevcuttur. Bu gruplar araştırmaya dahil edilmemiştir ve toplam katılım 91 kişi ile sınırlandırılmak zorunda kalınmıştır. $\mathrm{Bu}$ sayı "aktif çalışan kent konseyi üyeleri"nin tamamını içermektedir.

Araştırmada veri toplama tekniği olarak kullanılan anket sorularına Ek:1'den ulaş1labilir. Oluşturulan anket formunda kent konseyi üyelerinin bütçe bilgi düzeylerini ölçmeye ve çözüm önerileri getirmeye yönelik sorular sorulmuştur. Anket sonucunda elde edilen veriler analiz edilerek bütçe algıları ölçülmüş ve kent konseyi üyelerinin katılımcı bütçe açısından öneminin farkındalığ

Kent konseyi üyelerinin bütçe algılarının ölçüldüğü bu araştırmada oluşturulan anket formu dört bölümden oluşmaktadır. Bunlar aşağıdaki gibidir:

-Demografik bilgileri tespit etmeye ilişkin sorular,

-Kent konseyi üyelerinin genel bütçe bilgisine sahip olup olmadığına yönelik sorular, 
-Kent konseyi üyelerinin bütçe süreci hakkındaki bilgi düzeylerini ölçmeye ilişkin sorular,

-Kent konseyi üyelerinin, katılımcı bütçe açısından kent konseyi olarak öneminin farkında olup olmadığına dair sorular.

Çalışmada;

i) bütçe ile ilgili genel bilgi (GB) dağarcığının

ii) belediye bütçe süreci (BS) bilgi dağarcığının

iii) katılımc1 bütçe perspektifinden kent konseyi (KK) önemi farkındalığının

iki demografik parametre olan "cinsiyet" ve "eğitim düzeyi" açısından farklılaşıp farklılaşmadığı araştırılmıştır. Bu bağlamda aşağıdaki 6 sıfır hipotezi test edilmiştir.

$\mathrm{H1}_{0}$ : Kent konseyi üyelerinin bütçe ile ilgili genel bilgi dă̆arciğl cinsiyete göre farklılı göstermemektedir.

H20: Kent konseyi üyelerinin belediye bütçe süreci hakkndaki bilgi dăgarcı̆̆ cinsiyet baklmindan farklılık göstermemektedir.

$\mathrm{H}_{0}$ : Kent konseyi üyelerinin katılimcı bütçe perspektifinden kent konseyinin öneminin farkındalığ c cinsiyete göre farklılık göstermemektedir.

H40: Kent konseyi üyelerinin bütçe ile ilgili genel bilgi dă̆arcı̆ğ eğitim düzeyine göre farklllık göstermemektedir.

H50: Kent konseyi üyelerinin belediye bütçe süreci hakktndaki bilgi dă̆arcı̆̆ l ĕ̊itim düzeyine göre farklllık göstermemektedir

H6: Kent konseyi üyelerinin katulımcl bütçe perspektifinden kent konseyinin öneminin farkındalı̆̆ ĕgitim düzeylerine göre farklılık göstermemektedir.

Hipotez testleri gerçekleştirilmeden önce değişkenlerin normal dağılımı sahip olup olmadıklarının araştıılması gerekir. Değişkenlerin normal dağılıma uymaması durumunda, parametrik olmayan hipotez testleri kullanılmaktadır.

$\mathrm{Bu}$ amaçla çalışmada öncelikle normallik testleri gerçekleştirilmiştir. Örneklem büyüklügüünün 50'den küçük olması durumunda Shapiro-Wilk, büyük olması durumunda ise, Kolomogrov-Smirnov testi uygulanır. Araştırma 91 gözlem üzerinden yürütüldüğünden, GB (genel bilgi), BS (bütçe süreci) ve KK (kent konseyinin önemi) boyutlarına verilen cevapların normal dağılım gösterip göstermediği Kolomogrov-Smirnov testi ile analiz edilmiştir.

Hipotezlerin testinde, bütçe ile ilgili genel bilgi dağarcığı, belediye bütçe süreci bilgi dağarcığı ve katılımc1 bütçe perspektifinden kent konseyi önemi farkındalığı boyutlarının demografik özelliklere göre faklılık içerip içermediği analiz edilirken, boyutların normal dağılıma sahip olması ya da olmaması kullanılacak testi etkiler. Yani parametrik ya da parametrik olmayan testler kullanılır. Buna ek olarak demografik özelliklerin boyutları da test seçimini etkileyen bir başka faktördür. Cinsiyet "kadın ve erkek" olmak üzere iki boyuttan, eğitim düzeyi ise "ilköğretimi lise, lisans, yüksek lisans ve doktora" olmak üzere beş boyuttan oluşmaktadır. 
$\mathrm{Bu}$ açıklamalar doğrultusunda, bulgular başlığı altında test değerleri sunulacak olan ve normal dağılım göstermeyen "bütçe ile ilgili genel bilgi (GB) dağarcığı" ile "katılımcı bütçe perspektifinden kent konseyi (KK) önemi farkındalı̆̆ı" boyutlarının cinsiyete göre farklılığının analizinde Mann-Whitney U testi kullanılmıştır. Normal dağılım gösteren "belediye bütçe süreci (BS) bilgi dağarcığı" boyutunun cinsiyete göre farklılığg ise bağımsız örneklem t testi ile analiz edilmiştir.

Daha önce açıklandığı gibi eğitim düzeyi anket formunda 5 boyutlu dizayn edilmiştir. Dolayısıyla iki boyutlu analizlere uygulanabilen Mann-Whitney U ve bağımsız örneklem t testleri burada kullanılamamaktadır. Araştırmada normal dağılım göstermeyen "bütçe ile ilgili genel bilgi (GB) dağarcığı" ile "katılımcı bütçe perspektifinden kent konseyi (KK) önemi farkındalığı" boyutlarının eğitim düzeyine göre farklılığının analizinde Kruskal-Wallis H testi kullanılmıştır. Normal dağılım gösteren "belediye bütçe süreci (BS) bilgi dağarcığı" boyutunun cinsiyete göre farkl11lğ 1 ise ANOVA testi ile analiz edilmiştir.

Son olarak kent konseyi üyelerinin bütçe ile ilgili genel bilgi dağarcığının ve belediye bütçe süreci hakkındaki bilgi dağarcığının katılımcı bütçe perspektifinden kent konseyinin öneminin farkındalığı üzerindeki etkilerini belirlemek amacıyla regresyon analizi uygulanmıştır. Analiz sürecinde SPSS programından faydalanılmıştır.

\subsection{Araştırmanın Bulguları}

Araştırmada elde edilen bulgulara geçmeden önce, uygulanan anketin güvenilirliğine ilişkin test değerinin sunulması gerekmekedir. Ölçeklerin güvenilirliğini tespit etmek için Cronbach Alfa katsayısı( $\alpha$ ) kullanılmıştır. İç tutarlık katsayısını ifade eden Cronbach Alfa 0 ile 1 arasından bir değer almakta ve 0,70 değerinin üzerinde bulunması ölçeğin güvenilirliğini göstermektedir.

Bütçe algısının ölçülmesine yönelik oluşturulan veriler 5'li likert tarzı ölçek sorularından oluşmaktadır. Bu bölüme ilişkin hesaplanan Cronbach-Alfa değeri Tablo 1'de yer almaktadır.

Tablo 1: Cronbach's Alpha Değeri

\begin{tabular}{|c|c|c|}
\hline \multicolumn{3}{|c|}{ Reliability Statistics } \\
\hline Cronbach's Alpha & $\begin{array}{c}\text { Cronbach's Alpha Based on Standardized } \\
\text { Items }\end{array}$ & N of Items \\
\hline, 929 &, 937 & 36 \\
\hline
\end{tabular}

Kullanılan ölçeğin güvenilirliğini ölçmek amacıyla kullanılan Alfa modeline ilişkin Tablo 1'de yer alan sonuca göre, ölçeğe ait güvenilirlik katsayısı 0.929 olarak elde edilmiştir. Dolayısıyla kullanılan ölçek, yüksek derece güvenilir bir ölçektir.

Kent üyelerinin bütçe algılarının ölçüldüğg̈ ve yüz yüze görüşme yoluyla gerçekleştirilen araştırmaya ilişkin veriler aşağıdaki gibidir:

\subsubsection{Demografik Bulgular}

Ankete ilişkin veriler Tablo 2'de yer almaktadır. Ankete 40'1 kadın, 51'i erkek olmak üzere toplam 91 kişi katılım göstermiştir. Katılımcılardan 18 ile 24 yaş arasında olanlar 17 kişi, 25 ile 30 yaş arasında olanlar 8 kişi, 31 ile 39 yaş 
arasında olanlar 21 kişi, 40 ile 49 yaş arasında olanlar 35 kişi, 50 ile 59 yaş arasında olanlar 7 kişi, 60 yaş ve üstünde olanlar 3 kişidir. Katılımcıların eğitim düzeyine bakıldığında, 9 kişi ilköğretim, 17 kişi lise, 50 kişi lisans, 13 kişi yüksek lisans ve 2 kişi doktora mezunudur.

Tablo 2: Demografik Özellikler

\begin{tabular}{|c|c|c|c|}
\hline & & Frekans & Yüzde \\
\hline \multirow{2}{*}{ Cinsiyet } & Kadın & 40 & $\% 44$ \\
\hline & Erkek & 51 & $\% 56$ \\
\hline \multirow[t]{6}{*}{ Yaş } & $18-24$ & 17 & $\% 18.7$ \\
\hline & $25-30$ & 8 & $\% 8.8$ \\
\hline & $31-39$ & 21 & $\% 23.1$ \\
\hline & $40-49$ & 35 & $\% 38.5$ \\
\hline & $50-59$ & 7 & $\% 7.7$ \\
\hline & 60 ve üstü & 3 & $\% 3.3$ \\
\hline \multirow[t]{5}{*}{ Eğitim } & İlköğretim & 9 & $\% 9.9$ \\
\hline & Lise & 17 & $\% 18.7$ \\
\hline & Lisans & 50 & $\% 54.9$ \\
\hline & Yüksek lisans & 13 & $\% 14.3$ \\
\hline & Doktora & 2 & $\% 2.2$ \\
\hline \multirow[t]{9}{*}{ Kurum türü } & $\begin{array}{l}\text { Kamu kurum ve kuruluş } \\
\text { temsilcisi }\end{array}$ & 2 & $\% 2.2$ \\
\hline & Üniversite temsilcisi & 1 & $\% 1.1$ \\
\hline & Sendika temsilcisi & 1 & $\% 1.1$ \\
\hline & Baro temsilcisi & 1 & $\% 1.1$ \\
\hline & Dernek temsilcisi & 25 & $\% 27.5$ \\
\hline & $\begin{array}{lr}\text { Kamu } & \text { kurumu } \\
\text { niteliğindeki } & \text { meslek } \\
\text { kuruluşu } & \\
\end{array}$ & 1 & $\% 1.1$ \\
\hline & Siyasi parti temsilcisi & 2 & $\% 2.2$ \\
\hline & $\begin{array}{l}\text { Kent konseyi meclisi ve } \\
\text { çalışma } \\
\text { temsilcisi }\end{array}$ & 29 & $\% 31.9$ \\
\hline & Diğer & 29 & $\% 31.9$ \\
\hline
\end{tabular}

Kent konseyinde temsil edilen kurum/kuruluş türüne göre, 2 kişi kamu kurum ve kuruluş temsilcisi, 1 kişi üniversite temsilcisi, 1 kişi sendika temsilcisi, 1 kişi baro temsilcisi, 25 kişi dernek temsilcisi, 1 kişi kamu kurumu niteliğindeki meslek kuruluşu, 2 kişi siyasi parti temsilcisi, 29 kişi kent konseyi meclisi ve çalışma grupları temsilcisi ve 29 kişi diğer kategorisinde yer almaktadır.

\subsubsection{Normal Dağılım Testi}

Çalışmada, her bir alt boyut altında yer alan ifadelerin ortalaması alınarak GB (genel bilgi), BS (bütçe süreci) ve KK (kent konseyinin önemi) değişkenleri oluşturulmuştur. Hipotez testleri gerçekleştirilmeden önce değişkenlerin normal dağılımı sahip olup olmadıklarının araştırılması gerekir. Değişkenlerin normal dağılıma uymaması durumunda, parametrik olmayan hipotez testleri kullanılmaktadır.

Verilerin normal dağılım özellikleri Kolmogorov-Smirnov ve ShapiroWilk testleri veya çarpıklık ve basıklık değerlerinin kendi standart hatasına bölünmesi ile araştırılabilmektedir. GB, BS ve KK değişkenlerine ilişkin sonuçlar Tablo 3'de verilmiştir. 
Tablo 3: Normal Dağılım Testleri

\begin{tabular}{|c|c|c|c|}
\hline & GB & BS & KK \\
\hline \multirow{2}{*}{ Ortalama } & 4.0804 & 3.9541 & 4.1244 \\
& $(0.09743)$ & $(0.07246)$ & $(0.07989)$ \\
\hline \multirow{2}{*}{ Çarpıklık } & -1.399 & -0.527 & -1.206 \\
& $(0.263)$ & $(0.263)$ & $(0.263)$ \\
\hline \multirow{2}{*}{ Basıklık } & 2.342 & 0.208 & 2.841 \\
& $(0.520)$ & $(0.520)$ & $0.520)$ \\
\hline Kolmogorov-Smirnov & $0.155^{* * *}$ & 0.066 & $0.116^{* * *}$ \\
\hline \multicolumn{2}{|c|}{ Shapiro-Wilk } & $0.856^{* * * *}$ & $0.970^{* * *}$ \\
\hline Not: Parantez içindeki rakamlar standart hatalarl göstermektedir. & ve \\
\hline
\end{tabular}
düzeyindeki anlamlllıklarl ifade etmektedir.

Tablo 3'e göre, GB ve KK değişkenleri için Kolmogorov-Smirnov ve Shapiro-Wilk testlerinde verinin normal dağılıma sahip olduğunu söyleyen sifır hipotezi 0.05 önem seviyesinde reddedilmektedir. Ayrıca çarpıklık ve basıklık değerleri +1 ile - 1 değerlerinin dışında ve kendi standart hatasına bölünmesi sonucu elde edilen değerler 3.2'nin üstündedir. Dolayısıyla, bu değişkenler normal dağılım özelliği göstermemektedir. Bununla birlikte, BS değişkeni için KolmogorovSmirnov testinde sıfır hipotezi kabul edilmektedir. Ayrıca, bu değişken için çarpıklık ve basıklık değerleri +1 ile -1 arasındadır ve bu değerlerin kendi standart hatasına bölünmesi sonucu bulunan değerler 3.2'nin altındadır. Bu nedenle, BS değişkeni normal dağılım özelliği göstermektedir.

\subsubsection{Hipotez Testleri}

Araştırmada kurulan 6 sıfır hipotezinin testinde aşağıda özetlenmeye çalışılan adımlardan yararlanılmıştır.

\begin{tabular}{|c|c|c|c|}
\hline \multicolumn{4}{|c|}{ NORMAL DAĞILIM (Kolmogorov-Smirnov) } \\
\hline \multicolumn{2}{|c|}{ VAR } & \multicolumn{2}{|c|}{ YOK } \\
\hline $\begin{array}{c}\text { Cinsiyet } \\
\text { (İki boyutlu) }\end{array}$ & $\begin{array}{l}\text { Eğitim Düzeyi } \\
\text { (Beş boyutlu) }\end{array}$ & $\begin{array}{c}\text { Cinsiyet } \\
\text { (İki boyutlu) }\end{array}$ & $\begin{array}{l}\text { Eğitim Düzeyi } \\
\text { (Beş boyutlu) }\end{array}$ \\
\hline Bağımsız örneklem t-testi & ANOVA & Mann-Whitney U-testi & Kruskal-Wallis H-testi \\
\hline \multicolumn{4}{|c|}{ TEST EDİLEN HIPPOTEZLER } \\
\hline$H 2_{0}$ & $H 5_{0}$ & $H 1_{0}, H 3_{0}$ & $H 4_{0}, H 6_{0}$ \\
\hline
\end{tabular}

Çalışmada kadın ve erkek katılımcılar arasında kent konseyi üyelerinin bütçe ile ilgili genel bilgi dağarcığının farklılık gösterip göstermediğini incelemek amaciyla parametrik olmayan hipotez testlerinden Mann-Whitney $U$ testi uygulanmıştır. Sonuçlar Tablo 4 ve Tablo 5'da yer almaktadır.

H10: Kent konseyi üyelerinin bütçe ile ilgili genel bilgi dağarcığı cinsiyete göre farklılık göstermemektedir.

H1 $1_{1}$ Kent konseyi üyelerinin bütçe ile ilgili genel bilgi dağarcığı cinsiyete göre farklılık göstermektedir. 
Tablo 4: Örneklem Sıralama İstatistikleri

\begin{tabular}{|c|c|c|c|c|}
\hline & Cinsiyetiniz & N & Mean Rank & Sum of Ranks \\
\hline \multirow{3}{*}{ GB } & Kadın & 40 & 50,20 & 2008,00 \\
\cline { 2 - 5 } & Erkek & 51 & 42,71 & 2178,00 \\
\cline { 2 - 5 } & Total & 91 & & \\
\hline
\end{tabular}

Tablo 5: Mann-Whitney U Testi İstatistikleri

\begin{tabular}{|c|c|}
\hline \multicolumn{2}{|c|}{ Test Statistics $^{\mathbf{a}}$} \\
\hline & GB \\
\hline Mann-Whitney U & 852,000 \\
\hline Wilcoxon W & 2178,000 \\
\hline Z & $-1,358$ \\
\hline Asymp. Sig. (2-tailed) &, 175 \\
\hline a. Grouping Variable: cinsiyetiniz
\end{tabular}

Mann-Whitney U testi sonucunda test istatistiği değeri 852 ve buna karş1lık gelen olasılık değeri 0.175 olarak elde edilmiştir. Olasılık değeri 0.05 önem seviyesinden yüksek olduğu için sıfır hipotezi kabul edilmektedir. Kadın ve erkek katılımcılar arasında kent konseyi üyelerinin bütçe ile ilgili genel bilgi dağarcığı farkl111k göstermemektedir.

Kadın ve erkek kent konseyi üyelerinin belediye bütçe süreci hakkındaki bilgi dağarcığı arasında anlamlı bir farklılık olup olmadığını test etmek amacıyla parametrik hipotez testlerinden bağımsız örneklem t-testi uygulanmıştır. Sonuçlar Tablo 6 ve Tablo 7'de gösterilmektedir.

H2 0 : Kent konseyi üyelerinin belediye bütçe süreci hakkındaki bilgi dağarcığı cinsiyet bakımından farklılık göstermemektedir.

H2 : Kent konseyi üyelerinin belediye bütçe süreci hakkındaki bilgi dağarcığı cinsiyet bakımından farklılık göstermektedir.

Tablo 6: Grup İstatistikleri

\begin{tabular}{|l|c|c|c|c|c|}
\hline \multicolumn{7}{|c|}{ Group Statistics } \\
\hline \multirow{3}{*}{ BS } & Cinsiyetiniz & N & Mean & Std. Deviation & Std. Error Mean \\
\cline { 2 - 6 } & Kadın & 40 & 4,0372 &, 62626 &, 09902 \\
\cline { 2 - 6 } & Erkek & 51 & 3,9132 &, 72914 &, 10312 \\
\hline
\end{tabular}

Tablo 7: Bağımsız Örneklem t Testi

\begin{tabular}{|c|c|c|c|c|c|c|c|c|c|c|}
\hline \multicolumn{11}{|c|}{ Independent Samples Test } \\
\hline & & $\begin{array}{l}\text { Level } \\
\text { for Ec } \\
\text { Var }\end{array}$ & $\begin{array}{l}\text { s Test } \\
\text { lity of } \\
\text { aces }\end{array}$ & \multicolumn{7}{|c|}{ T-test for Equality of Means } \\
\hline & & \multirow[t]{2}{*}{$\mathrm{F}$} & \multirow[t]{2}{*}{ Sig. } & \multirow[t]{2}{*}{$\mathrm{T}$} & \multirow[t]{2}{*}{ Df } & \multirow[t]{2}{*}{$\begin{array}{l}\text { Sig. (2- } \\
\text { tailed) }\end{array}$} & \multirow[t]{2}{*}{$\begin{array}{c}\text { Mean } \\
\text { Difference }\end{array}$} & \multirow[t]{2}{*}{$\begin{array}{l}\text { Std. Error } \\
\text { Difference }\end{array}$} & \multicolumn{2}{|c|}{$\begin{array}{l}\text { 95\% Confidence } \\
\text { Interval of the } \\
\text { Difference }\end{array}$} \\
\hline & & & & & & & & & Lower & Upper \\
\hline \multirow{2}{*}{ BS } & $\begin{array}{c}\text { Equal } \\
\text { variances } \\
\text { assumed }\end{array}$ & ,735 & ,394 & ,853 & 88 & ,396 & ,12404 & ,14541 &,- 16493 & 41300 \\
\hline & \begin{tabular}{|c|} 
Equal \\
variances \\
not assumed
\end{tabular} & & & ,868 & 87,526 & ,388 & ,12404 & ,14296 &,- 16009 & ,40817 \\
\hline
\end{tabular}


40 kadın katılımcının ortalaması 4.0372 ve 51 erkek katılımcının ortalaması 3.9132'dir. Kadın ve erkek katılımcılar belediye bütçe süreci hakkındaki bilgi dağarcığına yönelik sorulara ortalama olarak katılıyorum görüşüne yakın cevap vermişlerdir. Bağımsız örneklem t testi sonucunda test istatistiği değeri 0.853 ve olasılık değeri 0.396 olarak bulunmuştur. Dolayısıyla, Kadın ve erkek kent konseyi üyelerinin belediye bütçe süreci hakkındaki bilgi dağarcığı arasında anlamlı bir farkl1lik yoktur.

Kent konseyi üyelerinin katılımcı bütçe perspektifinden kent konseyinin öneminin farkındalığının cinsiyet açısından farklılık gösterip göstermediğini incelemek amaciyla, parametrik olmayan hipotez testlerinden Mann-Whitney U testi uygulanmıştır. Sonuçlar Tablo 8 ve Tablo 9'da yer almaktadır.

$\mathrm{H3}_{0}$ : Kent konseyi üyelerinin katılımcı bütçe perspektifinden kent konseyinin öneminin farkındalığı cinsiyete göre farklılık göstermemektedir.

$\mathrm{H3}_{1}$ : Kent konseyi üyelerinin katılımcı bütçe perspektifinden kent konseyinin öneminin farkındalığı cinsiyete göre farklılık göstermektedir.

Tablo 8: Örneklem Siralama İstatistikleri

\begin{tabular}{|l|c|c|c|c|}
\hline & Cinsiyetiniz & N & Mean Rank & Sum of Ranks \\
\hline \multirow{3}{*}{ KK } & Kadın & 39 & 46,10 & 1798,00 \\
\cline { 2 - 5 } & Erkek & 45 & 39,38 & 1772,00 \\
\cline { 2 - 5 } & Total & 84 & & \\
\hline
\end{tabular}

Tablo 9: Mann-Whitney U Testi İstatistikleri

\begin{tabular}{|c|c|}
\hline \multicolumn{2}{|c|}{ Test Statistics $^{\mathbf{a}}$} \\
\hline & KK \\
\hline Mann-Whitney U & 737,000 \\
\hline Wilcoxon W & 1772,000 \\
\hline Z & $-1,265$ \\
\hline Asymp. Sig. (2-tailed) &, 206 \\
\hline a. Grouping Variable: cinsiyetiniz \\
\hline
\end{tabular}

Mann-Whitney U testi sonucunda test istatistiği değeri 737 ve buna karşıl1k gelen olasılık değeri 0.206 olarak elde edilmiştir. Dolayısıyla, 0.05 önem seviyesinde sıfır hipotezi kabul edilmektedir. Kadın ve erkek kent konseyi üyelerinin katılımcı bütçe perspektifinden kent konseyinin öneminin farkındalığ 1 farkl111k göstermemektedir.

Çalışmada kent konseyi üyelerinin bütçe ile ilgili genel bilgi dağarcığının eğitim düzeyine göre farklılık gösterip göstermediğini test etmek amaciyla parametrik olmayan hipotez testlerinden Kruskal-Wallis testi uygulanmıştır. Sonuçlar Tablo 10 ve tablo 11'de yer almaktadır.

$\mathrm{H4}_{0}$ : Kent konseyi üyelerinin bütçe ile ilgili genel bilgi dağarcı̆̆ı eğitim düzeyine göre farklılık göstermemektedir.

$\mathrm{H4}_{1}$ : Kent konseyi üyelerinin bütţe ile ilgili genel bilgi dağarcı̆̆ı eğitim düzeyine göre farklıık göstermektedir. 
Tablo 10: Gruplara İlişkin İstatistikler

\begin{tabular}{|c|c|c|c|}
\hline \multirow{4}{*}{ GB } & Eüitim Durumu & $\mathbf{N}$ & Mean Rank \\
\cline { 2 - 4 } & İlkögretim & 9 & 48,61 \\
\cline { 2 - 4 } & Lise & 17 & 39,41 \\
\cline { 2 - 4 } & Lisans & 50 & 49,31 \\
\cline { 2 - 4 } & Yüksek Lisans & 13 & 40,04 \\
\cline { 2 - 4 } & Doktora & 2 & 46,25 \\
\cline { 2 - 4 } & Total & 91 & \\
\hline
\end{tabular}

Tablo 11: Kruskal-Wallis Testi Sonucu

\begin{tabular}{|c|c|}
\hline \multicolumn{2}{|c|}{ Test Statistics $^{\text {a,b }}$} \\
\hline Chi-Square & GB \\
\hline Df & 2,649 \\
\hline Asymp. Sig. & 4 \\
\hline a. Kruskal Wallis Test &, 618 \\
\hline b. Grouping Variable: egitim durumu \\
\hline
\end{tabular}

Kruskal-Wallis testi sonucunda test istatistiği değeri 2.649'u olasılık değeri 0.618 olarak bulunmuştur. Dolayısıyla, 0.05 önem seviyesinde sıfır hipotezi kabul edilmektedir. Kent konseyi üyelerinin bütçe ile ilgili genel bilgi dağarcı̆̆ eğitim düzeyine göre farklılık göstermemektedir.

Kent konseyi üyelerinin belediye bütçe süreci hakkındaki bilgi dağarcığının eğitim düzeyine göre farklılık gösterip göstermediğini test etmek amaciyla parametrik hipotez testlerinden tek faktörlü varyans analizi uygulanmıştır. Sonuçlar Tablo 12, Tablo 13 ve Tablo 14'de yer almaktadır.

H50: Kent konseyi üyelerinin belediye bütçe süreci hakkındaki bilgi dağarcığı eğitim düzeyine göre farklılık göstermemektedir.

H51: Kent konseyi üyelerinin belediye bütçe süreci hakkındaki bilgi dağarcığı eğitim düzeyine göre farklılık göstermektedir.

Tablo 12: Örnekleme İlişkin İstatistikler

\begin{tabular}{|c|c|c|c|c|c|c|c|c|}
\hline \multicolumn{9}{|c|}{ BS } \\
\hline & \multirow[t]{2}{*}{$\mathrm{N}$} & \multirow[t]{2}{*}{ Mean } & \multirow[t]{2}{*}{$\begin{array}{c}\text { Std. } \\
\text { Deviation }\end{array}$} & \multirow[t]{2}{*}{$\begin{array}{l}\text { Std. } \\
\text { Error }\end{array}$} & \multicolumn{2}{|c|}{$\begin{array}{l}95 \% \text { Confidence } \\
\text { Interval for Mean }\end{array}$} & \multirow[t]{2}{*}{ Minimum } & \multirow[t]{2}{*}{ Maximum } \\
\hline & & & & & $\begin{array}{l}\text { Lower } \\
\text { Bound }\end{array}$ & $\begin{array}{l}\text { Upper } \\
\text { Bound }\end{array}$ & & \\
\hline İlköğretim & 9 & $\begin{array}{c}3,999 \\
4\end{array}$ & ,56288 & , 18763 & 3,5667 & 4,4321 & 3,14 & 5,00 \\
\hline Lise & 17 & $\begin{array}{c}3,893 \\
0\end{array}$ &, 78543 & ,19050 & 3,4892 & 4,2969 & 2,79 & 5,00 \\
\hline Lisans & 50 & $\begin{array}{c}4,008 \\
6\end{array}$ & ,74074 & ,10582 & 3,7959 & 4,2214 & 1,86 & 5,00 \\
\hline $\begin{array}{l}\text { Yüksek } \\
\text { Lisans }\end{array}$ & 13 & $\begin{array}{c}3,882 \\
9\end{array}$ & ,46492 & ,12895 & 3,6020 & 4,1639 & 3,15 & 5,00 \\
\hline Doktora & 2 & $\begin{array}{c}4,035 \\
7\end{array}$ &, 25254 & ,17857 & 1,7667 & 6,3047 & 3,86 & 4,21 \\
\hline Total & 91 & $\begin{array}{c}3,968 \\
3\end{array}$ & ,68441 & ,07214 & 3,8250 & 4,1117 & 1,86 & 5,00 \\
\hline
\end{tabular}


Tablo 13: Varyansların Homojenliği Testi

\begin{tabular}{|c|c|c|c|}
\hline \multicolumn{4}{|c|}{ Test of Homogeneity of Variances } \\
\hline \multicolumn{3}{|c|}{ BS } & Sig. \\
\hline Levene Statistic & df1 2 &, 133 \\
\hline 1,817 & 4 & 85 & \\
\hline
\end{tabular}

Tablo 14: Tek Faktörlü Varyans Analizi Sonucu

\begin{tabular}{|c|c|c|c|c|c|}
\hline \multicolumn{7}{|c|}{ ANOVA } \\
\hline \multicolumn{7}{|c|}{ BS } \\
\hline & Sum of Squares & Df & Mean Square & F & Sig. \\
\hline Between Groups &, 289 & 4 &, 072 &, 148 &, 963 \\
\hline Within Groups & 41,400 & 85 &, 487 & & \\
\hline Total & 41,689 & 89 & & & \\
\hline
\end{tabular}

İlköğretim mezunu olan 9 katılımcının belediye bütçe süreci ile ilgili bilgi dağarcığına yönelik sorulara verdikleri cevapların ortalaması 3.9994, 17 lise mezunu katılımcinın ortalamas1 3.8930, 50 katılımcının ortalamas1 4.0086, 13 yüksek lisans mezunu katılımcının ortalaması 3.8829 ve 2 doktora mezunu katılımeinın ortalamasi 4.0357 'dir.

Tek faktörlü varyans analizinin uygulanabilmesi için varyansların homojenliği varsayımının sağlanması gerekmektedir. Tablo 13'deki sonuca göre, Levene istatistiği değeri 1.817 ve olasılık değeri 0.133 olarak elde edilmiştir. Dolayısıyla, 0.05 önem seviyesinde varyansların homojenliği varsayımı sağlanmıştır. Tablo 14'de yer alan tek faktörlü varyans analizi sonucuna göre ise, $\mathrm{F}$ istatistiği değeri 0.148 ve olasılık değeri 0.963 'dür. Dolayısıyla, sıfır hipotezi kabul edilmektedir. Kent konseyi üyelerinin belediye bütçe süreci ile ilgili bilgi dağarcığı eğitim düzeyin göre farklılık göstermemektedir.

Kent konseyi üyelerinin katılımcı bütçe perspektifinden kent konseyinin öneminin farkındalığ 1 eğitim düzeylerine göre farklılık gösterip göstermediğini incelemek amaciyla parametrik olmayan hipotez testlerinden Kruskal-Wallis testi uygulanmıştır. Sonuçlar Tablo 15 ve Tablo 16'de gösterilmektedir.

H6: Kent konseyi üyelerinin katılımcı bütçe perspektifinden kent konseyinin öneminin farkındalığı eğitim düzeylerine göre farklılık göstermemektedir.

H61: Kent konseyi üyelerinin katılımeı bütçe perspektifinden kent konseyinin öneminin farkındalığı eğitim düzeylerine göre farklılık göstermektedir.

Tablo 15: Gruplara İlişkin İstatistikler

\begin{tabular}{|c|l|c|c|}
\hline & Eğitim durumu & N & Mean Rank \\
\hline \multirow{4}{*}{ KK } & İlköğretim & 8 & 40,25 \\
\cline { 2 - 4 } & Lise & 14 & 45,50 \\
\cline { 2 - 4 } & Lisans & 47 & 45,03 \\
\cline { 2 - 4 } & Yüksek Lisans & 13 & 35,54 \\
\cline { 2 - 4 } & Doktora & 2 & 16,25 \\
\cline { 2 - 4 } & Total & 84 & \\
\hline
\end{tabular}


Tablo 16: Kruskal-Wallis H-Testi Sonucu

\begin{tabular}{|c|c|}
\hline \multicolumn{2}{|c|}{ Test Statistics $^{\mathbf{a}, \mathbf{b}}$} \\
\hline Chi-Square & KK \\
\hline Df & 4,192 \\
\hline Asymp. Sig. & 4 \\
\hline a. Kruskal Wallis Test &, 381 \\
\hline b. Grouping Variable: egitim durumu \\
\hline
\end{tabular}

Kruskal-Wallis H-testi sonucunda test istatistiği değeri 4.192 ve olasılık değeri 0.381 olarak elde edilmiştir. Olasılık değeri 0.05 'den yüksek olduğu için sıfır hipotezi kabul edilmektedir. Kent konseyi üyelerinin katılımcı bütçe perspektifinden kent konseyinin öneminin farkındalığı eğitim düzeylerine göre farkl111k göstermemektedir.

\subsubsection{Regresyon Analizi}

Kent konseyi üyelerinin bütçe ile ilgili genel bilgi dağarcığının ve belediye bütçe süreci hakkındaki bilgi dağarcığının katılımcı bütçe perspektifinden kent konseyinin öneminin farkındalığı üzerindeki etkilerini belirlemek amacıyla regresyon analizi uygulanmıştır. Sonuçlara Tablo 17, Tablo 18 ve Tablo 19'de yer verilmiştir.

Tablo 17: Tanımlayıcı İstatistikler

\begin{tabular}{|c|c|c|c|}
\hline \multicolumn{4}{|c|}{ Descriptive Statistics } \\
\hline & Mean & Std. Deviation & N \\
\hline Kent Konseyi Farkındalı̆̆ (KK) & 4,1244 &, 73216 & 84 \\
\hline Genel Bütçe Bilgisi (GB) & 4,0804 &, 89299 & 84 \\
\hline Bütçeleme Süreci (BS) & 3,9541 &, 66407 & 84 \\
\hline
\end{tabular}

Tablo 18: Model Özeti

\begin{tabular}{|c|c|c|c|c|c|c|c|c|c|c|}
\hline \multicolumn{11}{|c|}{ Model Summary $^{\mathrm{b}}$} \\
\hline \multirow[b]{2}{*}{$\begin{array}{l}\overline{0} \\
\overline{0} \\
\Sigma\end{array}$} & \multirow[b]{2}{*}{$\simeq$} & \multirow[b]{2}{*}{ 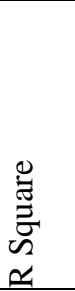 } & \multirow[b]{2}{*}{ 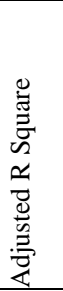 } & \multirow[b]{2}{*}{ 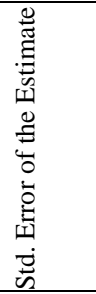 } & \multicolumn{5}{|c|}{ Change Statistics } & \multirow[b]{2}{*}{ 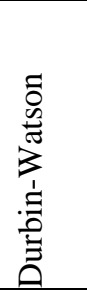 } \\
\hline & & & & & 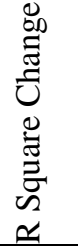 & 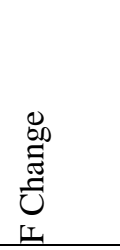 & $\bar{t}$ & $\stackrel{\mathbb{T}}{t}$ & 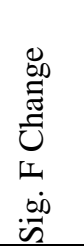 & \\
\hline 1 &, $687^{\mathrm{a}}$ & ,472 &, 459 & ,53841 & ,472 & 36,241 & 2 & 81 &, 000 & 1,527 \\
\hline \multicolumn{11}{|c|}{ a. Predictors: (Constant), BS, GB } \\
\hline
\end{tabular}

Ankete katılan katılımcılar bütçe ile ilgili genel bilgi dağarcı̆̆g, bütçe süreci hakkındaki bilgi dağarcığı ve kent konseyinin öneminin farkındalığına yönelik sorulara "katılıyorum"a yönelik cevap vermişlerdir. Kent konseyi üyelerinin bütçe ile ilgili genel bilgi dağarcı̆̆ 1 (GB) ve bütçe süreci hakkındaki bilgi dağarcığ (BS),kent konseyinin önemi farkındalığının (KK) \%47.2'sini açıklamaktadır. 
Başka bir deyişle farkındalık, bütçe bilgi dağarcığı ve bütçe sürecinden etkilenmektedir.

Tablo 19: Model Tahmin Sonucu

\begin{tabular}{|c|c|c|c|c|c|c|c|c|}
\hline \multicolumn{9}{|c|}{ Coefficients $^{\mathrm{a}}$} \\
\hline & \multirow[t]{2}{*}{ Model } & \multicolumn{2}{|c|}{$\begin{array}{l}\text { Unstandardized } \\
\text { Coefficients }\end{array}$} & \multirow{2}{*}{$\begin{array}{c}\text { Standardized } \\
\text { Coefficients }\end{array}$} & \multirow[t]{2}{*}{$\mathrm{t}$} & \multirow[t]{2}{*}{ Sig. } & \multicolumn{2}{|c|}{ Collinearity Statistics } \\
\hline & & $\mathrm{B}$ & Std.Error & & & & Tolerance & VIF \\
\hline \multirow[t]{3}{*}{1} & (Constant) & 1,103 &, 360 & & 3,060 & ,003 & & \\
\hline & GB & ,063 & ,088 & ,077 & ,720 & 474 & ,566 & 1,768 \\
\hline & BS & ,699 &, 118 & ,634 & 5,905 & ,000 & ,566 & 1,768 \\
\hline
\end{tabular}

Tablo 19'ye göre kent konseyi üyelerinin bütçe süreci ile ilgili bilgi dağarcığ 1 , kent konseyinin öneminin farkındalığı üzerinde anlamlı ve pozitif bir etkiye sahiptir. Söz konusu bulgu katılımcıların bütçe süreci bilgi dağarcığı arttıkça, farkındalık düzeyinin arttırdığı anlamına gelmektedir. Aynı etki bütçe hakkında genel bilgi dağarcığı ile farkındalık arasında mevcut değildir. Araştırma sonucunda ulaşılan bu durum, kent konseyi üyelerinin aslında teknik olarak genel bütçe bilgisine sahip olmamalarına karşın bütçe süreci hakkında bilgili olduklarını ortaya koymaktadır.

\section{SONUÇ VE DEĞERLENDİRME}

Vatandaşların kentsel yönetim süreçlerine daha aktif katılabilmeleri, kent yönetiminde söz sahibi olabilmeleri, farklı fikirlerin tartışılabildiği kentin ortak aklı olması bağlamında önemli görevler yüklenen kent konseyleri katılımcı bütçeleme anlayışı ile belediye bütçelerinin hazırlanması sürecinde önem kazanmaktadır.

Üzerinde durulması gereken temel noktalardan biri şudur ki çalışmanın temelini oluşturur; kent konseyi üyelerinin kararlarını alırken bütçe algılarının nasıl olduğu ve bu noktada, bütçe ve bütçeleme süreci hakkında bilgi sahibi olup olmamalarıdır. Ayrıca, bu durumun ölçülmesi de önemlidir. Çünkü bütçe ile ilgili bilgi sahibi olmayan bir konsey kıt kaynakların etkin kullanımı için doğru kararlar veremeyebilir ya da bu durumun farkında olamayabilir. Kent konseyi üyeleri bütçe hakkında yeterli bilgi ve beceriye sahip değil ise alınacak kararlarda kamu kaynaklarının israfı söz konusu olabilecektir ve bu anlamda çalışma önem arz etmektedir.

Çalışmada Manisa Yunusemre Belediyesi Kent Konseyi örneği ele alınarak katılımcı bütçe kapsamında üyelerin öncelikle demografik dağılımı belirlenmiş, sonrasında ise genel bütçe bilgisi, bütçe sürecine ilişkin bilgi düzeyleri ve bütçelemede kent konseyinin öneminin farkında olup olmamalarını ölçmeye yönelik bir anket uygulaması gerçekleştirilmiştir.

Yapılan analizler sonucu genel bilgi dağarcı̆̆ı (GB) ve bütçe süreci hakkındaki bilgi dağarcığı (BS), farkındalığın açıklanabilmesinde etkili faktörler 
olduğunu işaret etmiştir. Farkındalık üzerinde bütçe süreci ile ilgili bilgi dağarcığının pozitif anlamlı etkiye sahip olduğu da başka bir bulgudur.

Araştırma sonucunda ulaşılan bu durum, kent konseyi üyelerinin aslında teknik olarak genel bütçe bilgisine sahip olmamalarına karşın bütçe süreci hakkında bilgili olduklarını ortaya koymaktadır. Ancak bu noktada dikkat edilmesi gerekli bir durum söz konusudur: Teknik olarak bütçe bilgisine sahip olmamak bütçe sürecinde alınacak kararlarda hata yapma olasılığını arttırabilir. Bütçe süreci ile ilgili uygulamalar genel bütçe bilgisi ile desteklenmelidir.

Çalışmada Manisa Yunusemre Belediyesi Kent Konseyi'nin bütçe algısı ilk defa ölçülmüş ve yerel halka daha iyi hizmet sunabilmek için harcama önceliklerinin belirlenmesinde konsey üyelerinin yeterlilikleri hakkında bilgi edinilmiştir. Elde edilen bulgular ş̧ı̆̆ında konsey üyelerinin bütçe ile ilgili bilgi düzeyleri arttıkça bütçe sürecine daha etkin katılabilecekleri ifade edilebilir. Son olarak, belediye bütçe sürecinde, genel bütçe bilgisinin arttırılması sonucunda, hangi hizmetlerin sunulacağ 1 ve önceliklendirmesinin nasıl yapılacağı konularında yerel katılımın en önemli uygulaması olan kent konseyinin, kaynak kullanımında etkinliği arttırıcı etki yapabileceği düşünülmektedir.

\section{EK: Anket Formu}

\section{I.DEMOGRAFIK BILGILER}

\begin{tabular}{|c|c|}
\hline Cinsiyet & ( ) Kadın \\
\hline Yaş Grubu & $\begin{array}{lll}\text { ( ) } 18-24 & \text { ( ) } 25-30 & \text { ( )31-39 } \\
\text { ( ) } 40-49 & \text { ( ) } 50-59 & \text { ( )60 ve üstü } \\
\end{array}$ \\
\hline Eğitim Durumu & $\begin{array}{ll}\text { ( ) ) İlköğretim } & \text { ( ) Lise } \\
\text { ( ) Yüksek Lisans } & \text { ( ) Doktora } \\
\end{array}$ \\
\hline $\begin{array}{l}\text { Kent Konseyinde Temsil } \\
\text { Edilen Kurum/Kurulun Adı: }\end{array}$ & \\
\hline $\begin{array}{l}\text { Kent Konseyinde Temsil } \\
\text { Edilen Kurum/Kuruluşun Türü }\end{array}$ & 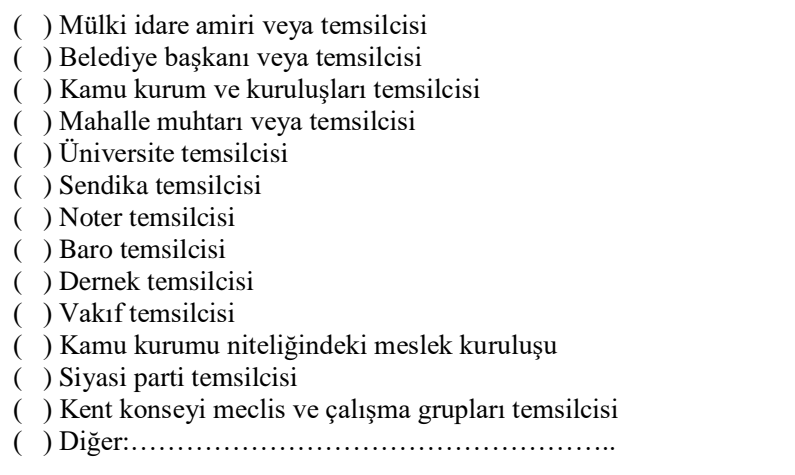 \\
\hline Kent Konseyi Görevi: & \\
\hline
\end{tabular}




\section{BÜTÇE ALGISI SORULARI}

\section{Aşağıda yer alan bilgilere katılım düzeyinizi 1: Kesinlikle Katılmıyorum 2:} Katılmıyorum 3: Kararsızım 4: Katılıyorum 5: Kesinlikle Katılıyorum ifadelerinden birisini işaretleyerek belirtiniz.

\begin{tabular}{|c|c|c|c|c|c|c|}
\hline \multicolumn{7}{|c|}{ Kent konseyi üyelerinin bütçe ile ilgili genel bilgi dağarcığına yönelik sorular; } \\
\hline 1 & Belediye bütçesi hazırlanırken belirli gelirler belirli giderlere tahsil edilemez. & 1 & 2 & 3 & 4 & 5 \\
\hline 2 & Bütçeler, izleyen iki yılın bütçe tahminleri ile birlikte hazırlanır. & 1 & 2 & 3 & 4 & 5 \\
\hline 3 & Bütçe bir meclis kararıdır. & 1 & 2 & 3 & 4 & 5 \\
\hline 4 & Belediye bütçesinde gelir ve gider denkliğinin sağlanması esastır. & 1 & 2 & 3 & 4 & 5 \\
\hline 5 & Kabul edilen bütçe, malî yılbaşından itibaren yürürlüğe girer. & 1 & 2 & 3 & 4 & 5 \\
\hline \multicolumn{7}{|c|}{ Kent konseyi üyelerinin belediye bütçe süreci hakkındaki bilgi dağarcığına yönelik sorular; } \\
\hline 6 & Bütün gelirler ve giderler gayrisafi olarak belediye bütçelerinde gösterilir. & 1 & 2 & 3 & 4 & 5 \\
\hline 7 & $\begin{array}{l}\text { Bütçelerle verilen ödenekler her harcama biriminin o biriminin başında bulunan } \\
\text { yöneticinin(harcama yetkilisinin) sahip olduğu harcama yapma yetkisinin sınırını } \\
\text { gösterir. }\end{array}$ & 1 & 2 & 3 & 4 & 5 \\
\hline 8 & $\begin{array}{l}\text { Belediye bütçesi stratejik plân ve performans programlarına uyumlu olarak } \\
\text { hazırlanır. }\end{array}$ & 1 & 2 & 3 & 4 & 5 \\
\hline 9 & Belediye meclisi gider artırıcı ve gelir azaltıcı değişiklikler yapamaz. & 1 & 2 & 3 & 4 & 5 \\
\hline 10 & $\begin{array}{l}\text { Bütçeleme sürecinde, yerel yönetim birimlerinin gelirleri merkezi yönetim } \\
\text { tarafindan kanunla belirlenir. }\end{array}$ & 1 & 2 & 3 & 4 & 5 \\
\hline 11 & $\begin{array}{l}\text { Bütçe hazırlanırken, harcamaları yerel yönetimlerin meclislerinin kararı olarak } \\
\text { kabul edilir ve uygulanır. }\end{array}$ & 1 & 2 & 3 & 4 & 5 \\
\hline 12 & $\begin{array}{l}\text { Meclis üyeleri, program dışı ödenek konulmasını ve programlı işlere ait ödeneğin } \\
\text { başka işlere aktarılmasını teklif edemezler. }\end{array}$ & 1 & 2 & 3 & 4 & 5 \\
\hline 13 & Meclis, bütçeyi bütünüyle reddedeme & 1 & 2 & 3 & 4 & 5 \\
\hline 14 & Kesin hesa & 1 & 2 & 3 & 4 & 5 \\
\hline 15 & Kesin hesabın görüşülmesi ve kesinleşmesinde, bütçeye ilişkin hükümler uygulanır. & 1 & 2 & 3 & 4 & 5 \\
\hline 16 & $\begin{array}{l}\text { Plan ve bütçe komisyonu aynı zamanda kesin hesap komisyonu olarak da görev } \\
\text { yapar. }\end{array}$ & 1 & 2 & 3 & 4 & 5 \\
\hline 17 & Ek ödenek verilmesi meclis kararı ile yapılır. & 1 & 2 & 3 & 4 & 5 \\
\hline 18 & Ek ödenek ancak büt & 1 & 2 & 3 & 4 & 5 \\
\hline 19 & $\begin{array}{l}\text { Ek ödenek verilmesi için yeni bir gelir veya finansman kaynağının bulunması } \\
\text { zorunludur. }\end{array}$ & 1 & 2 & 3 & 4 & 5 \\
\hline 20 & Yılsonunda kullanılmayan ödenekler bütün düzeyleri belirtilerek iptal edilir. & 1 & 2 & 3 & 4 & 5 \\
\hline 21 & Devredilen ödenek yeni yıl bütçesinde açılacak tertiplere ödenek kaydedilir. & 1 & 2 & 3 & 4 & 5 \\
\hline 22 & Ödenek iptali için üst yönetici onayı yeterlidir. & 1 & 2 & 3 & 4 & 5 \\
\hline 23 & Belediye Bütçesi iç denetim ve iç kontrol mekanizmasıyla denetlenir & 1 & 2 & 3 & 4 & 5 \\
\hline 24 & Belediyenin dış denetimi Sayıs & 1 & 2 & 3 & 4 & 5 \\
\hline \multicolumn{7}{|c|}{$\begin{array}{l}\text { Kent konseyi üyelerinin katılımcı bütçe perspektifinden kent konseyinin öneminin farkındalığına yönelik } \\
\text { sorular; }\end{array}$} \\
\hline 25 & $\begin{array}{l}\text { Kent konseyinin kararları belediye bütçesinin kaynaklarının doğru hizmetlere } \\
\text { yönlendirmesini kolaylaştırır. }\end{array}$ & 1 & 2 & 3 & 4 & 5 \\
\hline 26 & Kent konseyi, kentin stratejik yöneliminin belirlenmesinde önemli rol oynar. & 1 & 2 & 3 & 4 & 5 \\
\hline 27 & $\begin{array}{l}\text { Kent konseyleri vatandaşların ve sivil toplum kuruluşlarının bütçe sürecine ilgisinin } \\
\text { sürdürülmesi açısından gereklidir. }\end{array}$ & 1 & 2 & 3 & 4 & 5 \\
\hline 28 & Kent konseyinin belediye bütçesinin oluşum sürecine önemli katkısı olur. & 1 & 2 & 3 & 4 & 5 \\
\hline 29 & Kent konseyleri kent önceliklerinin belirlenmesinde en uygun alternatiftir. & 1 & 2 & 3 & 4 & 5 \\
\hline
\end{tabular}




\begin{tabular}{|c|c|c|c|c|c|c|}
\hline 30 & Kent konseyi kentteki tüm paydaşlardan oluşan ortak bir platform niteliğindedir. & 1 & 2 & 3 & 4 & 5 \\
\hline 31 & $\begin{array}{l}\text { Kent konseyi alınan yatırım ve hizmet kararlarının izlenmesi için ideal bir yapıyı } \\
\text { oluşturur. }\end{array}$ & 1 & 2 & 3 & 4 & 5 \\
\hline 32 & $\begin{array}{l}\text { Kent konseyi, kentin yaşam kalitesini geliştiren, çevreye duyarlı ve yoksulluğu } \\
\text { giderici programları destekler. }\end{array}$ & 1 & 2 & 3 & 4 & 5 \\
\hline 33 & $\begin{array}{l}\text { Kent konseyi, kente ilişkin faaliyet planlarının belirleme, uygulama ve izleme } \\
\text { süreçlerinde önemli rol oynar. }\end{array}$ & 1 & 2 & 3 & 4 & 5 \\
\hline 32 & Kent konseyi üyelerinin fikirleri yerel halkın fikirleriyle aynı yöndedir. & 1 & 2 & 3 & 4 & 5 \\
\hline 34 & Kent konseyi olarak belediye bütçesine katkı sağlamak hesap verilebilirliği arttırır. & 1 & 2 & 3 & 4 & 5 \\
\hline 35 & Kent konseyi olarak belediye bütçesine yapılan katkı saydamlığı sağlar. & 1 & 2 & 3 & 4 & 5 \\
\hline
\end{tabular}

KAYNAKÇA

Alkan, F., Yıldız, F. (2016). "Kamu Kurumlarının Bütçeleme Süreçlerinde Bireylerin Bütçe Algısı Üzerine Bir Araştırma", Electronic Journal of Vocational Colleges, C. 6, S. 2, 54-66.

Altıngöz Zarplı, S. (2017). Kamu Bütçelemesinde Yeni bir Yaklaşım Olarak Katılımcı Bütçeleme: Türkiye'de Belediyelere Yönelik Bir Araştırma, Osmangazi Üniversitesi SBE, Yayınlanmış Doktora Tezi.

Aydemir Uslu, İ., Yılmaz, H.H. (2018). "Yerel Yönetimlerde Katılımcılık:Kent Konseylerinin Rolü ve Bir Yapılandırma Önerisi", Çă̆daş Yerel Yönetimler Dergisi, C. 27, S. 1, 113-145.

Cura, S. (2003). Türkiye'de Mali Şeffaflığı Sağlamaya Yönelik Bir Uygulama: Analitik Bütçe Sinıflandırmas1, Marmara Üniversitesi İ̈BF Dergisi, C. 18, S. 1, 139-154.

Dağlı, E. (2017). Yerel Demokrasinin Sağlanmasında Katılımcı Bütçeleme: Bandırma ve Çanakkale Belediyelerindeki Yöneticilerin algısı, Yayınlanmamış Yüksek Lisans Tezi, Balıkesir SBE.

Eryılmaz, B. (2013). Kamu Yönetimi, Kocaeli:Umuttepe Yayınları.

Özcan L., Yurttaş, F. (2010). Kent Konseyleri Müzakereci Demokrasinin Uygulama Alanı Olarak Düşünülebilir mi?, Edt. Bekir Parlak, Yerel Yönetimler Yerel Siyaset ve Kentsel Politikalar, Dora Yayınc1lık, Bursa, 168-169.

Özen, A., Yontar, İ. G. (2009). Katılımcı Demokrasi Anlayışında Bütçeleme: Katılımcı Bütçeleme, Maliye Dergisi, Say1 156, Ocak-Haziran, 280-293.

Tekeli, İ. (1992). Belediyecilik Yazıları, IULA-EMME Yayını, İstanbul.

Yalçın, A. Z. (2015). Yerel Yönetimlerde Katılımcı Bütçeleme, Yönetim ve Ekonomi Dergisi, 22(2), 311-329.

Yıldız, F., Alkan, F. (2017). Katılımcı Bütçeleme Perspektifinden yükseköğretim Öğrencilerinin Bütçe Algısı Araştırması: Dumlupınar Üniversitesi Örneği, Maliye Araştırmaları Dergisi, Temmuz, S. 2, 129-145.

\section{SUMMARY}

In the study, the sample of Manisa Yunusemre Municipality City Council was determined and the demographic distribution of the members was determined within the scope of the participatory budget. Afterwards, a questionnaire was applied to measure general budget information, information about the budget process and the awareness of the importance of city council in budgeting.

As a result of the analysis, the knowledge and knowledge base on general knowledge and the budget process (BS) indicated that there were factors influencing awareness. It is another finding that knowledge base on awareness is related to the budget process.

As a result of the research, this situation shows that although the members of the city council do not have technical knowledge in general, they are aware of the budget process. At this point, however, there is a situation that needs attention: 
Not having the technical budget information can increase the likelihood of making mistakes in the decisions taken in the budget process. Practices related to budget process should be supported with general budget information.

In the study, the budget perception of the City Council of Manisa Yunusemre Municipality was measured for the first time. In order to provide better service to the local people, information on the qualifications of the council members was made in determining the expenditure priorities. In the light of the findings, it can be stated that the members of the council can participate more effectively in the budget process as their knowledge about the budget increases. Finally, in the municipal budget process, the city council, which is the most important implementation of local participation in the provision of services and prioritization is thought that the city council will have an effect on increasing the efficiency of resource use. 